\title{
MEMINIMASI PEMBOROSAN DENGAN LEAN MANUFACTURING PADA PROSES PRODUKSI DI PT. IE
}

\author{
Ahmad $^{1}$, Helena JK ${ }^{2}$, Andrean Yonathan ${ }^{3}$ \\ ${ }^{1}$ Program Studi Teknik Industri Universitas Tarumanagara \\ e-mail: ahmad@ft.untar.ac.id \\ ${ }^{2}$ Program Studi Teknik Industri Universitas Tarumanagara \\ e-mail: julianak@ft.untar.ac.id \\ ${ }^{3}$ Program Studi Teknik Industri Universitas Tarumanagara \\ e-mail: andrean.545170052@stu.untar.ac.id
}

\begin{abstract}
PT. IE is engaged in the business of making Lighting and Lampposts. Based on observations and interviews, there are still some wastes that arise in the flow of the production process, among which there are still many wastes of waiting time, transportation, movement and inventory. These wastes cause the product completion time to be longer and the resulting quality decreases. To eliminate or reduce waste, it is necessary to apply Lean Manufacturing. Lean Manufacturing is a systematic approach to eliminating waste and changing processes by identifying and reducing waste with continuous improvement and striving to create a production flow along the value stream by eliminating all forms of waste and increasing the added value of products to customers. From the Pareto diagram, it is found that transportation waste has the highest percentage of $26.21 \%$, waiting time is $21.38 \%$, motion waste is $19.31 \%$ and waste inventories are 15.17\%. while the results of the Value Stream Mapping Current State Map mapping obtained a production lead time of 7,680 seconds and a total cycle time of 6,660 seconds and a PCE Current State Map value of 53.09\%. Identify the root causes of waste using Fishbone diagrams, 5 Why Analysis, $5 W+1 H$, Fault Tree Analysis and FMEA. After corrective actions have been taken, based on the Value Stream Mapping Future mapping there is a decrease in production lead time to 5,220 seconds and a decrease in total cycle time to 4,860 seconds and an increase in PCE Future State Map to 68.10\% so that there is an increase of $15.01 \%$ which shows The company's production process has become more Lean.
\end{abstract}

Keywords: Lean Manufacturing, Waste, VSM, PCE.

\begin{abstract}
ABSTRAK
PT. IE bergerak dalam bisnis pembuatan Lighting dan Tiang Lampu. Berdasarkan observasi dan wawancara, masih terdapat beberapa pemborosan (waste) yang timbul di aliran proses produksi di antaranya masih banyak terjadi pemborosan-pemborosan waktu tunggu, transportasi, gerakan dan inventori. Pemborosan-pemborosan tersebut menyebabkan waktu penyelesaian produk menjadi lebih lama dan kualitas yang dihasilkan menurun. Untuk menghilangkan atau mengurangi pemborosan diperlukan adanya penerapan Lean Manufacturing. Lean Manufacturing merupakan pendekatan sistematik untuk mengeliminasi pemborosan dan mengubah proses dengan cara mengidentifikasi dan mengurangi pemborosan dengan perbaikan kontinu dan berupaya untuk menciptakan aliran produksi sepanjang value stream dengan menghilangkan segala bentuk pemborosan serta meningkatkan nilai tambah produk kepada pelanggan. Dari diagram Pareto ditemukan waste transportasi memiliki persentase paling tinggi sebesar 26,21\%, waktu tunggu $21,38 \%$, waste motion $19,31 \%$ dan waste inventories $15,17 \%$. sedangkan hasil pemetaan Value Stream Mapping Current State Map diperoleh production lead time selama 7.680 detik dan total cycle time selama 6.660 detik serta nilai PCE Current State Map sebesar 53,09\%. Identifikasi akar permasalahan pemborosan menggunakan diagram Fishbone, 5 Why Analysis, 5W+1H, Fault Tree Analysis dan FMEA. Setelah dilakukan tindakan-tindakan perbaikan, berdasarkan pemetaan Value Stream Mapping Future ada penurunan production lead time menjadi 5.220 detik dan penurunan total cycle time menjadi 4.860 detik serta ada peningkatan PCE Future State Map menjadi 68,10\% sehingga ada peningkatan 15,01\% yang menunjukan proses produksi perusahaan telah menjadi lebih Lean.
\end{abstract}

Kata Kunci: Lean Manufacturing, Waste, VSM, PCE.

\section{PENDAHULUAN}

\section{Latar Belakang}

PT. IE merupakan perusahaan manufaktur yang bergerak dalam bisnis Lighting dan Tiang Lampu. Salah satu produk yang diproduksi adalah tiang Penerangan Jalan Umum dengan sistem 
produksi berdasarkan permintaan pelanggan (make to order). Permasalahan yang dihadapi oleh perusahaan adalah masih adanya beberapa pemborosan (waste) yang timbul pada aliran proses produksi di antaranya adalah waktu tunggu, transportation, motion dan inventories. Dari pengamatan sering terlihat beberapa orang yang sedang menunggu pekerjaan dan menunggu menggunakan mesin bending sehingga hal ini dapat dikatakan sebagai pemborosan waktu tunggu. Selain tersebut ada data angka yang menunjukkan masih adanya barang setengah jadi (WIP) yang menunggu untuk diproses pada proses selanjutnya. Terlihat juga transportasi dari produk tiang Penerangan Jalan Umum (PJU) masih menggunakan kereta bantu secara manual sehingga menyebabkan waktu transportasi yang cukup lama dan juga memiliki jarak tempuh yang cukup jauh. Masalah lain yang ditemukan adalah adanya penumpukkan dari barang setengah jadi (WIP) di lantai produksi sehingga menyebabkan adanya tambahan inventory dan juga menimbulkan aktivitas penanganan tambahan yang seharusnya tidak diperlukan.

Untuk mengurangi masalah-masalah pemborosan tersebut dilakukan analisis menggunakan pendekatan Lean Manufacturing pada aliran proses produksi. Lean Manufacturing merupakan pendekatan sistematik untuk mengeliminasi pemborosan dan mengubah proses. Hal ini dilakukan dengan cara mengidentifikasi dan mengurangi pemborosan dengan perbaikan kontinu. Lean Manufacturing juga berupaya untuk menciptakan aliran produksi sepanjang value stream dengan menghilangkan segala bentuk pemborosan serta meningkatkan nilai tambah produk kepada pelanggan. Lean Manufacturing mendorong terciptanya fleksibilitas pada sistem produksi yang mampu beradaptasi secara cepat terhadap perubahan kebutuhan pelanggan dengan sistem produksi yang ramping dengan persediaan yang rendah. Selain itu, pendekatan ini dapat mengurangi unnecessary inventory, menambah pengetahuan mengenai proses produksi, menghemat biaya, pengurangan cacat sehingga kualitas meningkat, mengurangi lead time produksi dan mengurangi pemborosan (Farah, Putu dan Hari, 2012).

Tujuan yang hendak dicapai dalam penelitian ini adalah meminimalisir pemborosan/waste yang timbul pada aliran proses produksi dengan melakukan berbagai tindakan perbaikan yang sesuai dengan akar permasalahan dari setiap pemborosan (waste). Data yang diolah dalam penelitian ini adalah data primer yang dikumpulkan secara langsung, wawancara dan kuesioner serta data sekunder yang sudah ada di perusahaan seperti aliran proses bisnis perusahaan dan data waktu siklus proses produksi.

\section{Rumusan masalah}

Berdasarkan latar belakang yang sudah dijelaskan. Perusahaan masih mengalami permasalahan dan kendala berkaitan dengan pemborosan (waste) pada aliran proses produksinya. Hal ini menyebabkan tidak maksimalnya proses produksi yang berjalan dan berkurangnya kualitas produk yang dihasilkan kepada pelanggan. Untuk itu diusulkan metode Lean Manufacturing dalam mengidentifikasi dan meminimalisir pemborosan (waste) yang ada di aliran proses produksi sehingga tercipta proses produksi yang efisien dan efektif dalam memenuhi permintaan dan kebutuhan pelanggan. Dari identifikasi masalah didapatkan rumusan masalah adalah menjelaskan mengenai proses produksi tiang Penerangan Jalan Umum, menggambarkan kondisi perusahaan sekarang (current state map), mengetahui pemborosan apa saja yang ada pada proses produksi, mengidentifikasi akar permasalahan dari pemborosan yang terjadi, membuat usulan perbaikan dan menggambarkan kondisi perusahaan di masa yang akan datang (future state map) dengan menggunakan metode Lean Manufacturing, serta mengetahui tingkat perbaikan yang dihasilkan setelah penerapan usulan-usulan perbaikan.

\section{METODOLOGI PENELITIAN}

Langkah-langkah dalam metodologi penelitian dapat dilihat pada Gambar 1 berikut. 


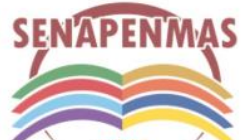

2021
Seminar Nasional Hasil Penelitian dan Pengabdian Kepada Masyarakat 2021 Pengembangan Ekonomi Bangsa Melalui Inovasi Digital Hasil Penelitian dan Pengabdian Kepada Masyarakat Jakarta, 21 Oktober 2021
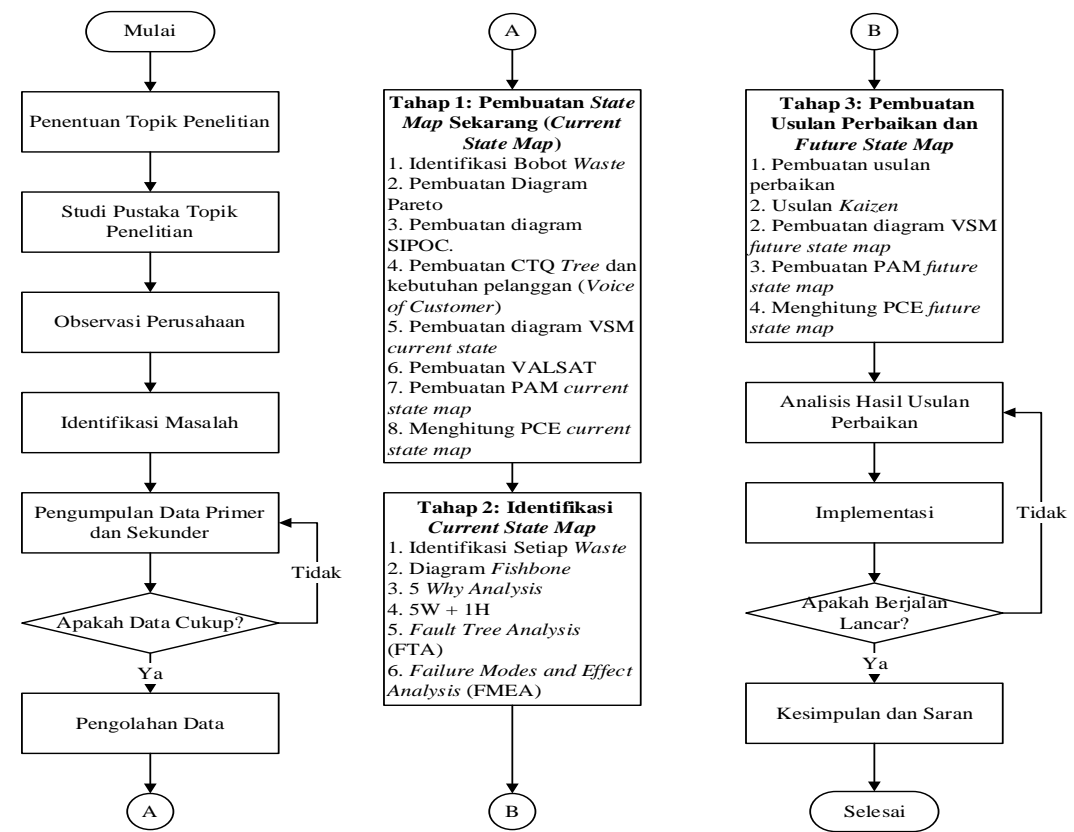

Gambar 1. Flowchart Metodologi Penelitian

\section{HASIL DAN PEMBAHASAN}

Setelah ditemukan berbagai waste di aliran proses produksi, maka selanjutnya dilakukan identifikasi bobot angka dari setiap jenis waste yang ada. Dalam mengidentifikasi bobot dari setiap waste, lima karyawan perusahaan diminta untuk mengisi kuisuiner penilaian. Hasil penilaian waste dapat di lihat pada Diagram Pareto gambar 2.

\section{Data Jumlah Total Penilaian Waste}

Jumlah Total Penilaian

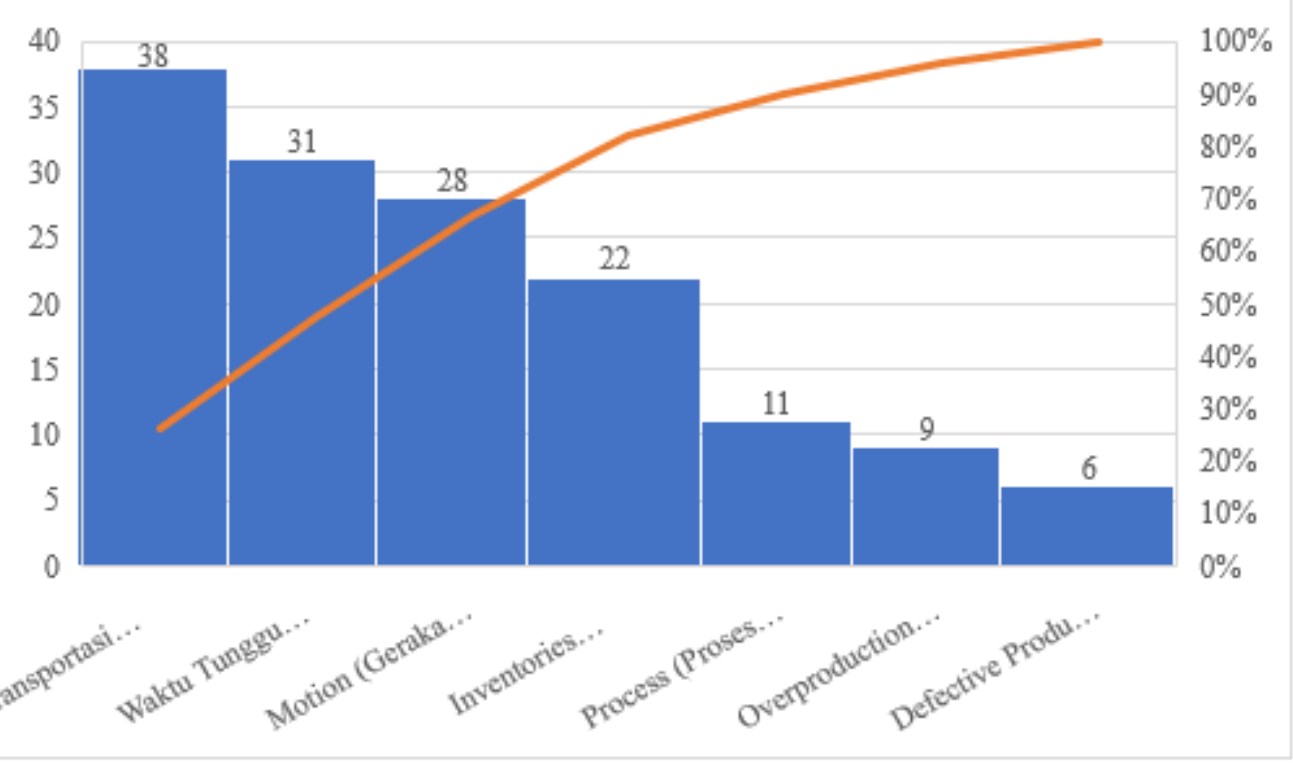

Gambar 2. Diagram Pareto Jenis Waste

Pada gambar 2 diketahui bahwa waste transportasi memiliki jumlah total penilaian yang paling banyak dengan total nilai sebesar $38(26,21 \%)$. Kemudian, diikuti pada peringkat kedua adalah waste waktu tunggu dengan total nilai sebesar $31(21,38 \%$, ) pada peringkat ketiga adalah waste 
motion dengan total nilai sebesar $28(19,31 \%$,) pada peringkat keempat adalah waste inventories dengan total nilai sebesar $22(15,17 \%)$, pada peringkat kelima adalah waste process dengan total nilai sebesar $11(7,59 \%$,) pada peringkat keenam adalah waste overproduction dengan total nilai sebesar $9(6,21 \%)$ dan pada peringkat ketujuh adalah waste defective products dengan total nilai sebesar $6(4,14 \%)$. Berdasarkan diagram pareto, waste yang harus diprioritaskan adalah waste transportasi, waktu tunggu, motion dan inventories karena persentase kumulatif keempat jenis waste ini sudah mencapai $82,07 \%$.

Beberapa aktivitas dan interaksi yang terjadi antara proses dengan elemen-elemen yang berada di luar proses perusahaan. Elemen - elemen yang berada di luar proses terdiri dari supplier, input, output dan customer (SIPOC). beberapa proses yang dilakukan untuk mendapatkan output yang diinginkan adalah Proses Shearing, Proses Bending/penekukan plat, Proses Las Titik (TIG Weld), Proses Las Panjang (Long Weld), Proses Las CO2 (Hand Weld), Proses Penghalusan, Proses Pelurusan, Proses Pengerolan, Proses Perakitan, dan Proses Cat Finishing.

Fokus permasalahan yang paling penting untuk memenuhi keinginan pelanggan adalah dengaan membuatkan karakteristik produk yang dapat digambarkan dalam Critical to Quality (CTQ) pada Gambar 3. Faktor dan dimensi kualitas yang dikehendaki dapat terlihat pada CTQ. CTQ Tree untuk memperingkat kualitas dan memecah tujuan kualitas menjadi dimensi-dimensi yang lebih kecil sehingga dapat mudah dipahami dan membuat masalah lebih mudah diselesaikan. Dari CTQ Tree ini dapat diketahui tindakan-tindakan apa saja yang harus dilakukan dalam memenuhi permintaan pelanggan yang nantinya dapat mencapai tujuan dari kualitas yang diinginkan oleh perusahaan.

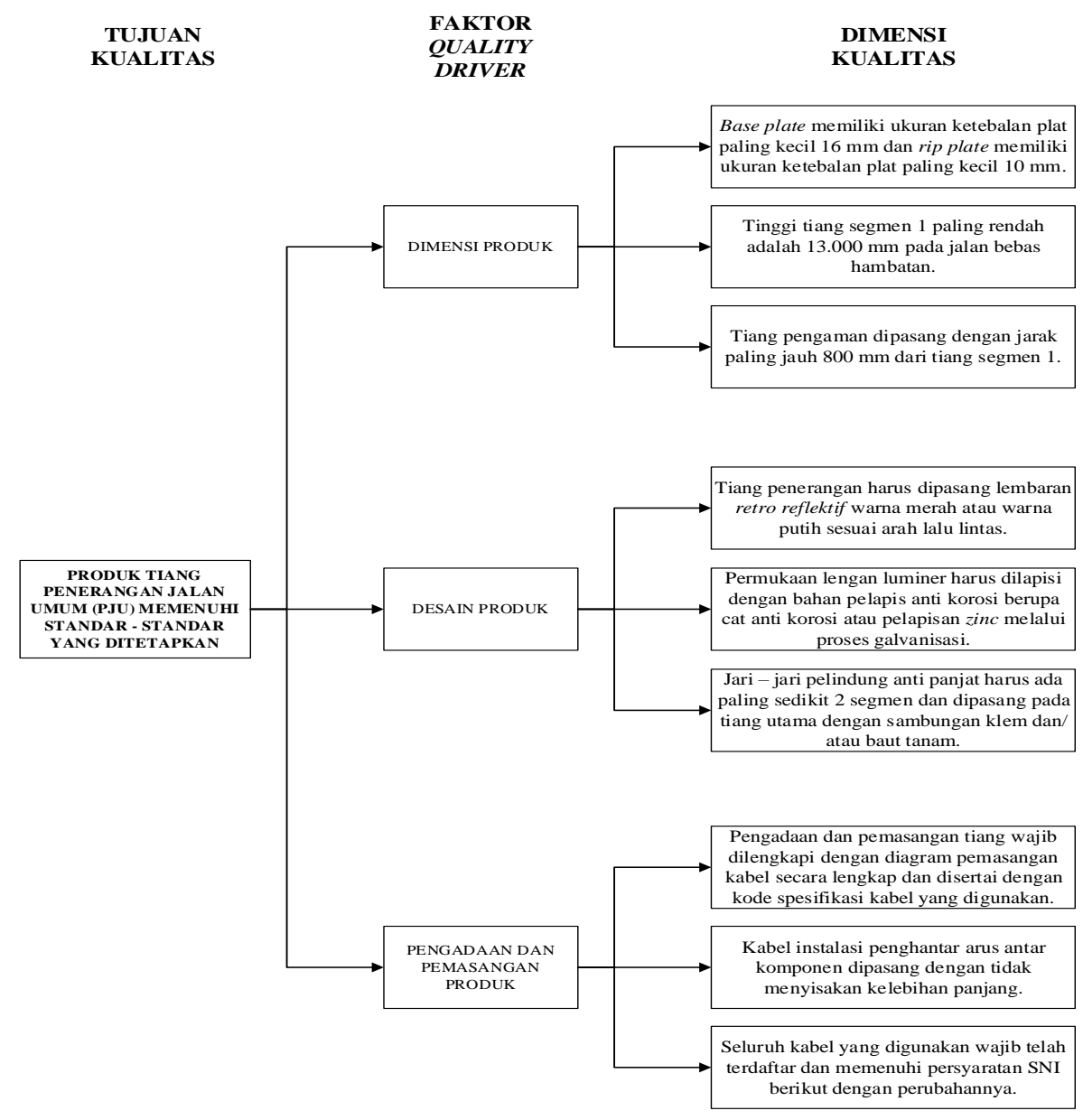

Gambar 3. CTQ produk 


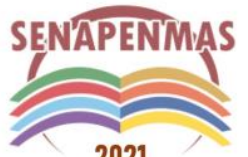

2021
Seminar Nasional Hasil Penelitian dan Pengabdian Kepada Masyarakat 2021 Pengembangan Ekonomi Bangsa Melalui Inovasi Digital Hasil Penelitian dan Pengabdian Kepada Masyarakat Jakarta, 21 Oktober 2021

Untuk mengidentifikasi kegiatan yang bersifat non-value added dan menemukan penyebab serta memberikan cara yang tepat untuk menguranginya adalah dengan pemetaan aliran sepanjang proses dengan Value Stream Mapping Current State Map. Berikut disajikan data-data yang dibutuhkan dalam pemetaan Value Stream Mapping Current State Map(VSM) yang dapat dilihat pada Tabel 1. Dari hasil pemetaan Value Stream Mapping Current State Map tersebut dapat dilihat bahwa production lead time selama 7.680 detik atau setara dengan 128 menit dengan total cycle time selama 6.660 detik atau setara dengan 111 menit.

Tabel 1. Data Pemetaan Value Stream Mapping Current State Map

\begin{tabular}{lccccc}
\hline Proses Produksi & $\begin{array}{c}\text { Waktu } \\
\text { Siklus } \\
\text { (Detik) }\end{array}$ & $\begin{array}{c}\text { Waktu } \\
\text { Changeover } \\
\text { (Detik) }\end{array}$ & $\begin{array}{c}\text { Waktu } \\
\text { Setup } \\
\text { (Detik) }\end{array}$ & $\begin{array}{c}\text { Available Time } \\
\text { per Hari } \\
\text { (Detik) }\end{array}$ & $\begin{array}{c}\text { Kapasitas } \\
\text { Mesin per } \\
\text { Hari (Unit) }\end{array}$ \\
\hline Proses Shearing & 480 & 120 & 600 & 21.600 & 75 \\
\hline Proses Bending & 540 & 180 & 600 & 21.600 & 50 \\
\hline Proses Las Titik & 360 & 120 & 300 & 21.600 & 50 \\
\hline Proses Las Panjang & 600 & 120 & 300 & 21.600 & 50 \\
\hline Proses Las CO2 & 360 & 120 & 300 & 21.600 & 50 \\
\hline Proses Penghalusan & 180 & 120 & 300 & 21.600 & 50 \\
\hline Proses Pelurusan & 180 & 120 & 300 & 21.600 & 50 \\
\hline Proses Pengerolan & 180 & 120 & 300 & 21.600 & 50 \\
\hline Proses Perakitan & 960 & 240 & 300 & 21.600 & 50 \\
\hline Proses Cat & 2.400 & 3.600 & 900 & 21.600 & 50 \\
Finishing & 300 & 300 & 300 & 21.600 & 50 \\
\hline Proses Packaging & & & & & \\
\hline
\end{tabular}

Hasil yang diperoleh dari wawancara langsung dengan direktur teknik dan produksi berkaitan dengan data waktu siklus, waktu changeover, waktu setup, available time per hari dan kapasitas mesin per hari dapat dilihat pada gambar 4. Value Stream Mapping Current State Map menggambarkan seluruh proses dari awal hingga akhir pada kondisi perusahaan sekarang sehingga dapat diketahui aktivitas yang bernilai tambah dan aktivitas yang tidak bernilai tambah di sepanjang aliran nilai sehingga dapat dilakukan perbaikan-perbaikan. 


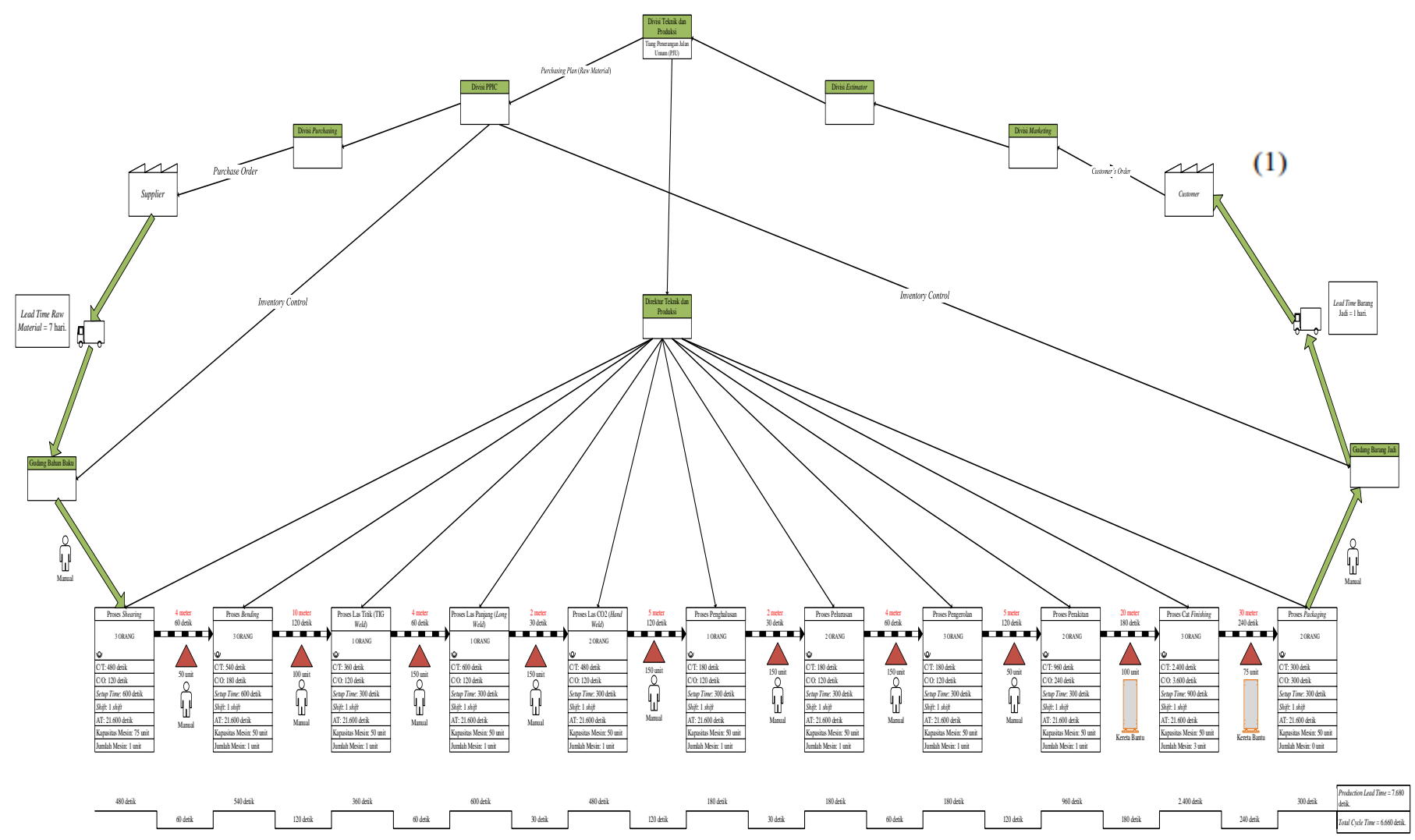

Gambar 4. Value Stream Mapping Current State Map PT IE

Process Activity Mapping (PAM) merupakan alat untuk mengeliminasi waste, inkonsistensi, keirasionalitas dari tempat kerja. Berdasarkan hasil pemetaan PAM Current State Map, dilakukan pengelompokkan aktivitas pada Tabel 2.

Tabel 2. Pengelompokkan Jenis Aktivitas

\begin{tabular}{clccc}
\hline No. & Jenis Aktivitas & Jumlah & Waktu (Menit) & \% Dari Jumlah \\
\hline 1 & VA & 12 & 103 & 37,5 \\
\hline 2 & NVA & 1 & 60 & 3,13 \\
\hline 3 & NNVA & 19 & 31 & 59,38 \\
\hline & Total & 32 & 194 & 100 \\
\hline
\end{tabular}

Berdasarkan Tabel 2, diperoleh nilai dari Value Added Time (VA) dan juga Total Lead Time, yang digunakan untuk menghitung Process Cycle Efficiency (PCE) Current State Map. Perhitungan PCE Current State Map yaitu dengan membandingkan value added time dengan total lead time sehingga di ketahui PCE sebesar 53,09 \%, Yang menunjukan bahwa PT.IE dapat disebut sudah Lean. Tetapi, masih terdapat pemborosan yang terjadi di aliran proses produksi sehingga diperlukan perbaikan-perbaikan untuk meminimalisir pemborosan tersebut.

Process Failure Mode and Effect Analysis (FMEA) merupakan salah satu teknik sistematis untuk menganalisis kegagalan proses yang sering ataupun berpotensi terjadi. Di dalam pembuatan analisis FMEA, terdapat pemberian nilai rating dari Severity $(\mathrm{S})$, Occurrence $(\mathrm{O})$ dan Detection (D) yang di mana nantinya digunakan dalam perhitungan Risk Priority Number (RPN) untuk menentukan prioritas penanganan dari setiap waste. Dalam menentukan nilai Severity (S) terdiri dari rating $1-10$, semakin parah akibat yang ditimbulkan, maka semakin tinggi nilai rating 
yang diberikan. Kemudian, dalam menentukan nilai Occurrence $(\mathrm{O})$ terdiri dari rating $1-10$ juga yang diberikan kepada penyebab dari setiap waste, semakin sering terjadi penyebab tersebut, maka semakin tinggi nilai rating yang diberikan. Lalu, yang terakhir adalah menentukan nilai Detection (D) yang terdiri dari rating $1-10$, semakin sulit penyebab waste dideteksi, maka semakin tinggi nilai rating yang diberikan. Untuk mendapatkan nilai Risk Priority Number (RPN) adalah dengan mengalikan ketiga nilai rating tersebut. Berdasarkan analisis FMEA, urutan tindakan perbaikan yang harus dilakukan pertama kali adalah tindakan perbaikan untuk meminimalisir waste waktu tunggu. Kemudian, tindakan perbaikan untuk meminimalisir waste transportasi, kemudian tindakan perbaikan untuk meminimalisir waste motion dan tindakan perbaikan untuk meminimalisir waste inventories.

Berikut ini tindakan perbaikan untuk meminimalisir setiap waste sesuai prioritas, yaitu:

1. Untuk Waste Waktu Tunggu, yaitu: Menginvestasikan pada pemasangan alat pengering atau oven untuk mempercepat proses pengeringan cat pada tiang di stasiun kerja cat finishing, Membuat papan informasi di lantai produksi untuk visual control pada aliran proses produksi, Menerapkan gerakan 5R/5S secara tertulis dan nyata di lantai produksi.

2. Tindakan Perbaikan Untuk Meminimalisir Waste Transportasi: Menginvestasikan alat bantu crane dengan panjang 25 meter dan berkapasitas hingga 12,5 ton untuk membantu aktivitas transportasi, Membuat ventilasi udara dan instalasi alat penyejuk udara di lantai produksi, Meningkatkan penerapan K3, Melakukan standarisasi waktu istirahat pada aktivitas transportasi menggunakan kereta bantu manual, usulan rancangan tata letak fasilitas, Menerapkan gerakan 5R/5S secara tertulis dan nyata di lantai produksi.

3. Tindakan Perbaikan Untuk Meminimalisir Waste Motion: Mengganti job desk salah satu karyawan untuk ditugaskan sebagai supervisor produksi untuk mengawasi jalannya aliran proses produksi, Melengkapi APD para pekerja, Menyediakan tempat penyimpanan barang di stasiun kerja cat finishing.

4. Tindakan Perbaikan Untuk Meminimalisir Waste Inventories, dengan cara Menginvestasikan alat bantu dengan panjang 25 meter dan berkapasitas hingga 12,5 ton untuk membantu aktivitas penyimpanan barang, Menyediakan tempat penyimpanan barang di sekitar area pengeringan cat pada tiang.

Berdasarkan usulan perbaikan yang telah disebutkan, selanjutnya dilakukan pemetaan Value Stream Mapping Future State Map untuk menggambarkan kondisi perusahaan di masa yang akan datang setelah dilakukannya perbaikan-perbaikan. Selanjutnya dilakukan pemetaan Process Activity Mapping Future State Map pada kondisi perusahaan di masa yang akan datang setelah dilakukannya perbaikan-perbaikan. Hasil dari PAM Future State Map ini nantinya akan digunakan kembali untuk menghitung PCE Future State Map. Berikut tabel 3 adalah pengelompokkan aktivitas hasil pemetaan Process Activity Mapping Future State Map.

Tabel 3. Pengelompokkan Jenis Aktivitas

\begin{tabular}{clccc}
\hline No. & Jenis Aktivitas & Jumlah & Waktu (Menit) & \% Dari Jumlah \\
\hline 1 & VA & 12 & 73 & 37,5 \\
\hline 2 & NVA & 1 & 15 & 3,13 \\
\hline 3 & NNVA & 19 & 19,19 & 59,38 \\
\hline & Total & 32 & 107,19 & 100 \\
\hline
\end{tabular}

Pada Tabel 3 diketahui bahwa jumlah dari aktivitas Value Added (VA) berjumlah 12 aktivitas dengan total waktu selama 73 menit, jenis aktivitas ini mengalami penuruan total durasi waktu yaitu dari 103 menit menjadi 73 menit. Kemudian, pada aktivitas Non-Value Added (NVA) berjumlah 1 aktivitas dengan total waktu selama 15 menit, jenis aktivitas ini mengalami penurunan total durasi waktu yaitu dari 60 menit menjadi 15 menit. Lalu yang terakhir, pada 
aktivitas Necessary but Non-Value Added (NNVA) berjumlah 19 aktivitas dengan total waktu selama 19,19 menit, jenis aktivitas ini mengalami penurunan total durasi waktu yaitu dari 31 menit menjadi 19,19 menit. Tabel 4 Hasil analisa dari perbandingan antara VSM Current State Map dengan VSM Future State Map.

Tabel 4. Perbandingan VSM Current State Map dengan VSM Future State Map

\begin{tabular}{lccc}
\hline Kategori Waktu & VSM Current State Map & VSM Future State Map & Keterangan \\
\hline Lead time Produksi & 7680 detik & 5.220 detik & Menurun \\
& & & 2.460 detik \\
\hline Total Cycle time & 6.660 detik & 4.860 detik & Menurun \\
& & & 1.800 detik \\
\hline
\end{tabular}

Tabel 4 menunjukan terjadi penurunan production lead time sebesar 2.460 detik atau setara dengan 41 menit sehingga menjadi 5.220 detik atau setara dengan 87 menit dan penurunan total cycle time sebesar 1.800 detik atau setara dengan 30 menit sehingga menjadi 4.860 detik atau setara dengan 81 menit. Sedangkan nilai perhitungan PCE Future State Map sebesar 68,1\% yaitu ada peningkatan sebesar 15,01\%. Dimana PCE Current State Map sebesar 53,09\%. Peningkatan nilai PCE menunjukkan bahwa pemborosan (waste) sudah diminimalisir sehingga dapat dikatakan bahwa proses produksi perusahaan telah menjadi lebih Lean.

\section{KESIMPULAN}

1. Terdapat empat waste tertinggi yang timbul di aliran proses produksi tiang dengan kumulatif sudah mencapai $82,07 \%$, empat waste tertinggi tersebut adalah waste transportasi $26,21 \%$, waste waktu tunggu 21,38\%, waste motion $19,31 \%$ dan waste inventories sebesar $15,17 \%$.

2. Pada pemetaan VSM Current State Map diperoleh production lead time sebesar 7.680 detik dan total cycle time sebesar 6.660 detik serta PCE Current State Map sebesar 53,09\%.

3. Tindakan-tindakan perbaikan melalui pemetaan VSM Future State Map didapatkan penurunan production lead time menjadi 5.220 detik dan penurunan total cycle time menjadi 4.860 detik serta didapatkan peningkatan PCE Future State Map menjadi 68,10\%.

\section{Ucapan Terima Kasih (Acknowledgement)}

Penelitian ini mendapat hibah dari Direktorat Penelitian dan Pelayanan Masyarakat Universitas Tarumanagara, Jakarta, Indonesia. Dengan demikian maka pada kesempatan ini, Penulis ingin mengucapkan terima kasih kepada lembaga LPPM Untar dan juga kepada semua orang yang membantu Penulis untuk menyelesaikan penelitian ini.

\section{REFERENSI}

A. Nugroho, M. Ainuri, dan N. Khuriyati, 2015."Reduksi Pemborosan Untuk Perbaikan Value Stream Produksi "Mi Lethek" Menggunakan Pendekatan Lean Manufacturing," Jurnal AGRITECH, Vol. 35, No. 02, Mei 2015, pp. 205 - 211, Jurusan Teknologi Industri Pertanian, Fakultas Teknologi Pertanian, Universitas Gadjah Mada, Yogyakarta, Indonesia. Ahmad, Lithrone Laricha Salomon dan Jesica, 2018.'Desain Eksperimen Untuk Meningkatkan Kualitas Kekuatan Produk Dengan Pendekatan Analisis Desain Faktorial," Jurnal Ilmiah Teknik Industri, Vol. 06, No. 03, 2018, pp. 209 - 220, Fakultas Teknik, Jurusan Teknologi Industri, Program Studi Teknik Industri, Universitas Tarumanagara, Jakarta, Indonesia.

B. Wijayanto, A. Saleh, dan E. Zaini, 2015.'Rancangan Proses Produksi Untuk Mengurangi Pemborosan Dengan Penggunaan Konsep Lean Manufacturing di PT. Mizan Grafika Sarana," Jurnal Online Institut Teknologi Nasional, Vol. 03, No. 01, Januari 2015, pp. 119 - 129, Jurusan Teknik Industri, Institut Teknologi Nasional (Itenas) Bandung, Bandung, Indonesia. 
Caesara Octavia and Helena J. Kristina. 2016.”Measurement of Performance on TKO 2x36w Lamp Housing Line Production at PT. Wingslite Sejahtera by Using Lean \& Green Manufacturing Approach," Proceedings of the $2^{\text {nd }}$ ILCAN Conference Series on Life Cycle Assessment, 2-3 November 2016, pp. 64 - 74, Department of Industrial Engineering, Universitas Pelita Harapan, Kelapa Dua, Tangerang City, 15811, Indonesia.

F. Widyan Hazmi, P. Dana Karningsih, dan H. Supriyanto, 2012."Penerapan Lean Manufacturing Untuk Mereduksi Waste di PT. ARISU," Jurnal Teknik ITS, Vol. 01, No. 01, September 2012, pp. F-135 - F-140, Fakultas Teknologi Industri, Program Studi Teknik Industri, Institut Teknologi Sepuluh Nopember (ITS), Surabaya, Indonesia.

P. Hines, dan N. Rich, 1997.'The Seven Value Stream Mapping Tools," International Journal of Operations \& Productions Management, Vol. 17, No. 1, 1997, pp. 46-64, Lean Enterprise Research Centre, Cardiff Business School, Cardiff, UK.

T. Ristyowati, A. Muhsin, dan P. Puji Nurani, 2017."Minimasi Waste pada Aktivitas Proses Produksi dengan Konsep Lean Manufacturing (Studi Kasus di PT. Sport Glove Indonesia)," Jurnal Optimasi Sistem Industri, Vol. 10, No. 01, Juni 2017, pp. 85 - 96, Fakultas Teknik Industri, Jurusan Teknik Industri, Universitas Pembangunan Nasional "Veteran" Yogyakarta, Yogyakarta, Indonesia.

V. Gaspersz, dan A. Fontana, Lean Six Sigma for Manufacturing and Service Industries: Waste Elimination and Continuous Cost Reduction, 2011, Bogor: Vinchristo Publication. Halaman 4.

V. Gaspersz, Lean Six Sigma for Manufacturing and Industries : Strategi Dramatik Reduktif Cacat/Kesalahan, Biaya, Inventori dan Lead Time dalam Waktu Kurang dari 6 Bulan, 2007, Jakarta: Gramedia, Halaman 2.

W. Kosasih, Adianto, dan Erickson, 2015."Analisis Pengendalian Kualitas Produk Bucket Tipe ZX 200 GP dengan Metode Statistical Process Control dan Failure Mode and Effect Analysis (Studi Kasus: PT. CDE)," Jurnal Ilmiah Teknik Industri, Vol. 3, No. 2, pp. 85-93, Fakultas Teknik, Jurusan Teknologi Industri, Program Studi Teknik Industri, Universitas Tarumanagara, Jakarta, Indonesia. 
Seminar Nasional Hasil Penelitian dan Pengabdian Kepada Masyarakat 2021

Pengembangan Ekonomi Bangsa Melalui Inovasi Digital Hasil Penelitian dan

Pengabdian Kepada Masyarakat

Jakarta, 21 Oktober 2021

(halaman kosong) 